\title{
Schopenhauer's Thoughts on Holiness and the Projects of Moral Religion in the Age of Enlightenment in Germany
}

\author{
Ludmila Kryshtop \\ Peoples' Friendship University of Russia \\ Moscow, Russia \\ kryshtop_le@rudn.university
}

\begin{abstract}
Schopenhauer was interested in the philosophical tradition of Indians. He admitted himself that the thoughts of Vedas (among philosophy of Kant) was the important issue of his own philosophical views. It actually expressed in very many aspects of his philosophical doctrine, among all in his understanding of holiness that considered to be Schopenhauer as an essential aspect of every religion. Analyzing the main features of this holiness phenomenon, Schopenhauer concludes to the genuine kinship of Christianity and Hinduism and criticized the contemporary state of Christianity, but if we consider the views of Schopenhauer in more detail, we can find the origins of his views dated back to the Age of German Enlightenment.
\end{abstract}

Keywords-Schopenhauer; will; holiness; Christianity; Hinduism; religion; morality; Enlightenment; Kant; reason; faith

\section{INTRODUCTION}

Lately, one can often meet opinions that European culture in its different aspects (e.g. language, mythology, religion, moral and other spiritual dimensions) is derived from Indian culture. Not so much Indian culture on the whole, as we find it today in India, but from the oldest Indian doctrine based on the Vedas. We can and must state that this trend of thinking is not modern and dates back at least to the 19th century, and I think that the most well-known philosopher in that regard is Arthur Schopenhauer. It would be no exaggeration to say that Schopenhauer was the thinker who revealed Indian thoughts and Indian spiritual culture as a whole for Europeans. Certain information about Indians was known in Europe at least since the foundation of the first catholic mission in the 16th century, and, in Schopenhauer's time, there were already a lot of different official and nonofficial reports and stories of persons who worked in or visited India. There were also translations of the key Indian philosophical and religious texts, and other philosophers before Schopenhauer mentioned Indian gods, for example Kant, what indicates that this information was already wellknown for Europeans. But only Schopenhauer stated that Indian thought was so important that we could find the

The paper is prepared in the frames of the project supported by the grant of the Russian Science Foundation (RSF) Nom. 16-18-10427. ancient wisdom of mankind in a near-original form. That is the reason because Indian philosophy can help us to understand the essence (quiddity) of the world and things. That is why we find a lot of references and comparisons of Schopenhauer's own views and the Indian point of view, not in the way that the Indian philosophy can be interpreted as the ground for Schopenhauer's ideas but quite the opposite. Indian thought presents only one way the main truths about the world and life concerned by Schopenhauer in his works can realize in. As these truths have been corrupted in a less degree in India, Indian thought corresponds to be the best illustration for Schopenhauer's philosophical ideas.

On the other hand, there are a lot of discussions about the question of whether Schopenhauer's vision of Indian philosophy was right. Most researchers tend towards the opinion that Schopenhauer's vision was corrupted with incorrect translations he used, that is why it would just to speak not about the relationship between the Indian philosophy and Schopenhauer's philosophy but about the relationship between Schopenhauer's philosophy and his vision of Indian philosophy. I would not like to concern these special questions of Schopenhauer-studies in my quite shot consideration, but would like to regard the correlations and likeness of Schopenhauer's point of view and the Indian one so, as it was regarded by Schopenhauer himself. I would not like to regard the whole of these correlations (it might be a subject of a very large work) but only the one aspect of it, namely, the relationship between Christianity and Indian religions in regard to the phenomenon of holiness in Schopenhauer's philosophy. The other aspect I would like to turn on is the likeness of Schopenhauer's views on Christianity and the views on the relationship between moral and religion in the Age of Enlightenment in Germany.

\section{SCHOPENHAUER ABOUT HOLINESS}

It is well-known that Schopenhauer regarded European culture and European morality quite negatively and saw lack of value in them compared to the Indian culture. Europeans regarded all things in the world in the light of monotheism teaching: there is God, the Maker of the world and the human being as Lord of creation passing by the fact that quiddity of all the things in the world is one and the same. 
That is a metaphysical will: a will to live. If a human being understands it, he will not need anything else for moral life. If I accept that I am representation of the will and the other things in the world are also representations of the same will, I cannot hurt anyone in this world because I will not want to hurt to myself. This idea is the necessary and sufficient rule of morality. It must be expanded not only to human beings but also to animals and plants what we don't have in Europe because of the false mind based on the Old Testament that God has created a human being as a lord of all other kinds of creation and has given him the right to hold sway over them. Although this idea arose from Judaism, it was assumed by Christianity and so entered the European mindset. So, we can see that Schopenhauer's station on Christianity and its role in the development of mankind is rather critical and negative. In spite of this fact his most famous work, "The World as Will and Representation" says that holiness is one of two ways to win the will and to go out from its empire. We find a lot of examples of Christian saints in this work, but all Christian saints hold on to the Christian dogmatic regarded by Schopenhauer as false. How is it possible that the false way can lead to the right end?

I consider it necessary to study more precisely to analyze this paradox that Schopenhauer understood under holiness. Holiness is such a condition when the will reaches "full selfconsciousness, distinct and exhaustive knowledge of its own inner nature" [1]. That can happen only in a human being. Such knowledge, if it relates to the will itself, makes an elimination and self-denial of the will possible. The freedom belonging to the things-itself which cannot show itself in phenomena, appears in phenomena. The will abolishes "the essential nature at the root of the phenomenon, whilst the phenomenon itself still continues to exist in time, it brings about a contradiction of the phenomenon with itself" [1]. So, we get the phenomena of holiness and self-denial.

Holiness is nothing else than the result of the will's complete resignation from itself, "when it has reached the highest degree" [1]. It is "death to one's own will and regeneration in God" [1]. We can say using the words from the Gospels that it is "denying the self and taking of the cross upon oneself" [1]. The examples of such resignation from itself we find in all culture regions of the world that enables Schopenhauer to speak about holiness as a common phenomenon of mankind without ranging it to only one from all the religions. In this sense, we can also speak about the saints in Hinduism or Buddhism. Herewith the rules which could help to reach this condition of the will remain the same. They are the following: love of one's neighbor with complete denial of all self-love, charitableness even to the giving away of one's hard-won daily earnings, boundless patience towards all offenders; return of all evil, however bad it may be, with goodness and love; voluntary and cheerful endurance of every insult and ignominy; abstinence from all animal food; perfect chastity and renunciation of all sensual pleasure for him who aspires to real holiness and so on [1]. The same is also the thought that for the man who has attained perfection all outward works and religious practices are superfluous.

This agreement demonstrates in so many things that here we have to do with the essential side of human nature. It concerns the human will and not the mind. That is why saints can appear in all religions in the world. This phenomenon has not to do with dogmas or truths of faith, which are things of the mind. It is situated much deeper, at the root of human nature and deals with the dimension of freedom, of thingsitself or with other words with intuitive knowledge, and with intuitive apprehension of deeper or higher reality. The results of this intuitive work can hardly be expressed in terms of the mind. Different saints and mystics tried to do it relying on their faculty of reason impressed with accepted dogmas of their religions. Finally, we have a lot of saints that possess rather illogical superstitions, but it doesn't matter because the inner nature of holiness is determined not with outward rational expression in abstract terms but with denial of the will to live appeared after the complete knowledge of its own inner being. That is why, for us, it is much more important to see how saints lived in accordance with their intuitive apprehension and not how they explained it with the help of dogmas. In this context, all religions are equally bad and harmful because they are only parabolic descriptions of the truth claiming to be the truth itself.

However, we can say that the fate of Christianity seems to be more tragic than that of the Indian religions (Hinduism and Buddhism). Although Christianity and Indian religions have the same root since Jesus Christ was for some time in Egypt and the Egyptian religion is nothing else than a slight modification of doctrine of the Vedas, this Indian spiritual heritage fell on the ground of Judaism because of certain historical circumstances had to be brought in according to it. That is why, in Christian doctrine we have two quite different components hardly connected to each other components. They are an ethical component which is the same with the ethical teaching of Indian religions and a dogmatic one which arises from Judaism and is presented with monotheism [1]. Consequently, Christianity is very unstable and, according to Schopenhauer, will have to clear itself and eliminate this originally foreign Judaic component in the course of time. Here remains the question in what way Schopenhauer has thought of Christianity without monotheism and without the Judaic faith in Messiah, the Saviour. It must be an entirely different religion, but it is already a different topic for another study.

\section{SCHOPENHAUER AND THE VIEWS OF GERMAN ENLIGHTENERS ON MORAL AND RELIGION}

In Schopenhauer's rejection that the observance of outward ritual aspects of different religions (including Christianity) has value in itself and his statement at the same time the holiness as a specific condition of human will characterized by rejection of itself is the essential part of each religion we can see a significant similarity with the views of Kant. In his project of religion of reason, Kant supposed true religion must be one and the same for all human beings and so must be built on the absolutely necessary foundations of human reason and, thus, can be only the moral one. Hereby, Kant underlined the difference between historic religions (religions of revelation) and the religion of reason. The first include observance of ritual actions as the necessary component for they are binding 
condition of salvation and are considered to be placed by God the Almighty. The second can exist without this ritual elements and includes only the observance of the moral law. This is only one God would like to receive from His creations as a sing of their reverence to Him. All the ceremonies such as fast, pilgrimages, worships and the other of that kind are on the contrary superfluous and not expected or wished by God. They can be accepted only for they could be the means to create the true moral attitude, but it is false to regard them as the end in itself. In the future, when human society as a whole reaches the enlightenment, this kind of religion will be absolutely unnecessary and so eliminated [2].

In Kant's project of religion of pure reason, we can see the influences of preceding German philosophical tradition of conceptualization the relationship between moral and religion. So Chr. Thomasius hold for a founder of Enlightenment philosophy in German has already said the outward ceremonies of religions are necessary only for they are the fundament of social peace as outward sings the person adheres to the principles common for all members of the society [3]. God the Almighty does not need all these human establishments. The only one He expects from His creations is the observance of the commandment to love one's neighbor [1]. Such ideas we find also by Chr. Wolff bringing the matter of ceremonies to making the right inner mood [4]. Herewith, we see already the main difference between the tinkers of Early Enlightenment in German (even the most radical disposed) and the ones of Late Enlightenment. The enlighteners at the end of 18th century considered holiness as an absolute agreement of will condition of human being with the moral law requirements and supposed it could exist without any kind of religiosity. For the enlighteners of the first half of 18th century, holiness was also the absolute good will. It was evident for them that such will condition because of brokenness of human will through the Fall can be attained only by the agency of God's grace. Only this one enables a man to be that God intends him to be also in moral regards. The necessary condition of this God's help is the true faith that is the faith Christ is Our God and Lord which through His crucial sacrifice has redeemed our fault. In this way holiness included the morality as a necessary element but could not be reduced to it. That is why the morality of pagan philosophers (Greeks, Chinses, Indians) regarded at best as a lower degree of morality or as an only seeming morality [5].

\section{CONCLUSION}

The philosophy of Schopenhauer has the significant stage of reception of Indian culture in Europe either in philosophical and religious regards. His views on the nature of Christianity as a religion, which has the same base as Hinduism, can be considered a close relative to the latter laid a foundation of interreligious dialogue. At the same time, quite radical views of Schopenhauer on the holiness phenomenon which is an essential aspects of different religions have been caused with the preceding philosophical tradition of German Enlightenment that has found its expression in the practical philosophy of Kant and his project of moral religion based on observance the moral law requirements instead of ritual prescriptions of revealed religions which could be very different in different cultures and even contradict to each other.

\section{REFERENCES}

[1] A. Schopenhauer, The World as Will and Representation, in 2 vol., vol. 1. New York: Dover Publications, 1969.

[2] I. Kant, Religion within the Boundaries of Mere Reason and Other Writings. Cambridge: CUP, 1998, pp. 113, 173-174.

[3] Chr. Thomasius, Von der Kunst vernünftig und tugendhaft zu lieben, als dem einzigen Mittel zu einem glückseligen, galanten und vergnügten Leben zu gelangen, oder: Einleitung der Sitten-Lehre. Halle, 1726, p. 142

[4] Chr. Wolff, Vernünfftige Gedancken von der Menschen Thun und Lassen, zu Beförderung ihrer Glückseeligkeit. Halle, 71743, pp. 107109.

[5] Chr. Wolff, Rede über die praktische Philosophie der Chinesen Hamburg: Felix Meiner Verlag, 1985, pp. 27, 139. 